\title{
MODEL PEMBELAJARAN KOLABORATIF DAN ASESMEN AUTENTIK PADA PEMBELAJARAN BAHASA INGGRIS
}

\author{
Lilik Indriasasi Agustini \\ SMAN I Sesayap Hilir Kabupaten \\ Tana Tidung, Kalimantan Timur \\ Yuliatri Sastrawijaya \\ FT Universitas Negeri Jakarta, \\ Jakarta Timur
}

\section{Alamat Korespondensi e-mail: \\ axcelsyailendra05@gmail.com}

\begin{abstract}
The purpose of this research is to find out the effect of collaborative instructional model and authentic assessment towards student's English achievement. The method used was an experimental method. While the design used was the factorial $2 \times 2$ design. Research hypotheses were tested by using analysis of variance (ANOVA). This research concluded that STAD cooperative learning model can be paired with the authentic assessment of portfolio and project types in English learning. More over the Learning Model in English Learning must consider the use of alternative form of assessment.
\end{abstract}

Keywords

Collaborative instructional model, authentic assesment, the students English achievement.

\begin{abstract}
ABSTRAK
Penelitian ini bertujuan untuk melihat pengaruh model pembelajaran kolaboratif dan asesmen autentik terhadap hasil belajar Bahasa Inggris. Metode yang digunakan adalah metode eksperimen, dengan desain faktorial $2 \times 2$. Hipotesis penelitian diuji dengan menggunakan analisis varian (ANAVA) dua jalan. Hasil penelitian menyimpulkan bahwa model pembelajaran kooperatif STAD dapat disandingkan dengan asesmen autentik bentuk portofolio dan bentuk proyek dalam pembelajaran Bahasa Inggris kemudian penggunaan model pembelajaran dalam Bahasa Inggris juga perlu memperhatikan bentuk asesmen alternatif yang digunakan.
\end{abstract}

Kata Kunci

Model pembelajaran kolaboratif, asesmen autentik, hasil belajar Bahasa Inggris.

\section{Pendahuluan}

Bahasa Inggris adalah Bahasa Internasional dan pemersatu di mana tidak hanya sebagai alat komunikasi tetapi juga sebagai bahasa penghubung yang dipakai di seluruh dunia, yang mencakup aspek listening, writing, reading, dan speaking. Peran guru dalam menciptakan situasi pembelajaran yang aktif, efektif, dan menyenangkan serta pemilihan model pembelajaran dan bentuk penilaian yang sesuai sangat menentukan keberhasilan siswa dalam memahami Bahasa Inggris. Mengajar Bahasa Inggris bukan hanya sekedar mengajarkan komponen-komponen bahasa seperti grammar atau tata bahasa, vocabulary (kosakata), dan translation (penerjemahan) melainkan mengajarkan bagaimana bahasa itu digunakan sebagai alat untuk berkomunikasi dalam berbagai situasi sosial. Komunikasi dapat berbentuk formal dan tidak formal, dan dapat dilakukan secara lisan maupun tertulis (Darminah, 20II). Oleh karena itu siswa diharapkan dapat mengembangkan potensinya dengan tidak sekedar berbicara tetapi penguasaan kosakata, karena dalam materi Bahasa Inggris akan banyak ditemui bacaan-bacaan yang mengandung kata-kata sulit.

Guru sebagai salah satu komponen mempunyai peran yang sangat penting dalam menentukan hasil belajar peserta didik yang diharapkan. Untuk itu guru dituntut agar dapat lebih kreatif dan inovatif dalam menyusun rencana pembelajaran di kelas, sehingga dapat memberikan motivasi terhadap peserta didik dalam belajar untuk meningkatkan hasil belajar peserta didik sesuai dengan tujuan pembelajaran yang akan dicapai. Menurut A.J. Romizowsky hasil belajar yang dicapai oleh peserta didik ditunjukkan oleh adanya perubahan-perubahan pada diri peserta didik apakah itu pengetahuan, keterampilan, nilai, dan sikap. Hasil belajar merupakan keluaran (output) dari suatu sistem pemrosesan masukan (input), masukan dari sistem tersebut berupa bermacam-macam informasi sedangkan keluarannya adalah perbuatan atau kinerja (performance) (Jihad dan Harris, 2012). Jadi hasil 
belajar tersebut tidak hanya diperoleh dari membaca saja, tetapi pada saat akhir pembelajaran akan dapat diambil hasil dari proses belajar dengan bentuk penilaian. Secara sederhana, yang dimaksud dengan hasil belajar adalah kemampuan yang diperoleh anak setelah melalui kegiatan belajar. Dalam setiap proses pembelajaran anak akan selalu mendapatkan tambahan ilmu pengetahuan yang akan sangat berguna bagi kehidupannya sehari-hari.

Penilaian merupakan suatu kegiatan yang tak mungkin dipisahkan dari kegiatan pendidikan dan pengajaran secara umum. Semua kegiatan pendidikan yang dilakukan harus selalu diikuti atau disertai dengan kegiatan penilaian. Penilaian (assessment) adalah proses pengumpulan dan pengolahan informasi untuk mengukur pencapaian hasil belajar peserta didik (Kurniasih dan Sani, 20I4). Selama proses pembelajaran siswa berhak mendapatkan hasil tentang apa yang telah di dapat dan dipelajari pada saat proses pembelajaran dengan bentuk penilaian. Selanjutnya penilaian atau asesmen hasil belajar oleh pendidik yang dimaksudkan untuk mengukur kompetensi atau kemampuan tertentu terhadap kegiatan yang telah dilaksanakan dalam kegiatan pembelajaran (Hosnan, 20I4). Pada saat pembelajaran para guru dapat langsung memberikan penilaian pada siswa apakah materi yang telah disampaikan dapat diterima dengan baik atau belum tercapai sama sekali. Jadi pada dasarnya penilaian (assesmen) adalah proses atau tindakan mengumpulkan informasi dan mengukur kemampuan hasil belajar dari peserta didik berdasarkan hasil pengukuran sebelumnya dari kegiatan pengajaran dan pembelajaran sebagai usaha formal dan penentu status siswa yang berkaitan dengan pendidikan secara berkesinambungan dan menyeluruh yang mencakup aspek pengetahuan, keterampilan, sikap, dan nilai-nilai sejauh mana peserta didik telah mencapai pembelajaran berdasarkan kriteria dan pertimbangan tertentu.

Salah satu instrumen yang dibutuhkan dalam penilaian, yaitu: tes. Tes dapat diartikan sebagai alat yang dipergunakan untuk mengukur pengetahuan atau penguasaan proyek ukur terhadap seperangkat konten dan materi tertentu, serta dapat diartikan sebagai salah satu prosedur evaluasi yang komprehensif, sistematik dan objektif yang hasilnya dapat dijadikan dasar dalam pengambilan keputusan dalam prosedur pengajaran yang dilakukan oleh guru, Djaali dan Muljono (2008). Tes yang digunakan dalam penelitian ini, yaitu: tes pilihan ganda. Tes pilihan ganda pada dasarnya terdiri dari dua bagian, yaitu: batang tubuh tes, berupa pertanyaan pengantar atau pernyataan tidak lengkap dan dua atau lebih kemungkinan jawaban. Secara teknis jawaban yang benar disebut kunci jawaban dan yang lainnya disebut pengecoh.

Penilaian autentik (authentic assessment) merupakan penekanan dalam kurikulum 2013. Melalui kurikulum 2013 penilaian autentik menjadi penekanan yang serius di mana guru dalam melakukan penilaian hasil belajar peserta didik benar-benar memperhatikan penilaian autentik. Penilaian autentik itu sendiri adalah kegiatan menilai peserta didik yang menekankan pada apa yang seharusnya dinilai, baik proses maupun hasil dengan berbagai instrumen penilaian yang disesuaikan dengan tuntutan kompetensi yang ada di Standar Kompetensi (SK) atau Kompetensi Inti (KI) dan Kompetensi Dasar (KD) (Kunandar, 20l4). Brown menjelaskan bahwa asesmen autentik lebih menekankan pada pemberian tugas yang menuntut pembelajar menampilkan, mempraktikkan, atau mendemonstrasikan hasil pembelajarannya di dunia nyata secara bermakna yang mencerminkan penguasaan pengetahuan dan keterampilan dalam suatu mata pelajaran (Wahyuni dan Ibrahim, 20I2: 10). Penilaian nyata adalah proses yang dilakukan guru untuk mengumpulkan informasi tentang perkembangan belajar yang dilakukan siswa. Karakteristik penilaian autentik menurut Trianto adalah sebagai berikut: (I) dilaksanakan selama dan sesudah proses pembelajaran berlangsung, (2) dapat digunakan untuk formatif atau sumatif, (3) yang diukur keterampilan dan performansi, bukan mengingat fakta, (4) berkesinambungan, serta (5) terintegrasi, dan dapat digunakan sebagai feedback. Selanjutnya ada beberapa penilaian yang cocok digunakan dalam asesmen autentik, yaitu: (I) penilaian kinerja (performance assessment), (2) penilaian portofolio, (3) penilaian proyek, dan (4) penilaian tertulis (Hosnan, 20I4).

Paulson mendefinisikan Portofolio sebagai kumpulan pekerjaan siswa yang menunjukkan usaha, perkembangan, dan kecakapan mereka, di dalam satu bidang atau lebih (Rasyid dan Mansyur, 
2009). Di sini siswa diarahkan dalam berbaga macam pengumpulan hasil karya dari materi yang telah disampaikan dalam proses pembelajaran dan di akhir pertemuan. Johnson dan Johnson mendefinisikan "A portofolio is an organized collection of evidence accumulated over time on a student's or group's academic progress, achievements, skills, and attitudes." Jadi, portofolio merupakan koleksi dari bukti-bukti kemajuan siswa atau kelompok siswa, bukti prestasi, keterampilan, dan sikap siswa (Rasyid dan Mansyur, 2009). Dalam konteks pendidikan, bahwa portofolio merupakan kumpulan (koleksi) pekerjaan-pekerjaan yang terbaik yang dimiliki siswa baik berupa pekerjaan dalam arti tugastugas intrakurikuler maupun ekstrakurikuler, yang paling berarti sebagai hasil kegiatan belajarnya pada suatu bidang tertentu. Pengertian Portofolio adalah penilaian berkelanjutan yang didasarkan pada kumpulan informasi yang menunjukkan perkembangan kemampuan peserta didik dalam satu periode tertentu (Jihad dan Harris, 20I2). Karena pada dasarnya penilaian portofolio yang diambil adalah jenis penilaian portofolio perkembangan peserta didik jadi pada saat pemberian materi oleh guru informasi apapun yang berkaitan dengan pembelajaran haruslah disampaikan secara jelas, karena pada akhirnya akan sangat menentukan pengumpulanpengumpulan berbagai macam karya yang berkaitan dengan materi yang dibatasi oleh waktu baik individu maupun kelompok. Portofolio merupakan koleksi/kumpulan dari berbagai keterampilan ide, minat, dan keberhasilan atau prestasi siswa dalam jangka waktu tertentu. Portofolio merupakan suatu asesmen alternatif berdasarkan pada sampel karya siswa, memetakan evolusi pemahaman siswa terhadap suatu mata pelajaran, dan mendokumentasikan keterampilan siswa (Hosnan, 20l4). Menurut Majid portofolio merupakan suatu koleksi yang dikhususkan dari pekerjaan peserta didik yang mengalami perkembangan yang memungkinkan peserta didik dan guru menentukan kemajuan yang sudah dicapai oleh peserta didik (Wiyani, 20I3). Dikatakan pekerjaan peserta didik mengalami perkembangan karena mereka dapat merevisi pekerjaannya sesuai dengan self assesment-nya.

Dalam Penilaian Portofolio yang akan diteliti adalah jenis penilaian portofolio peserta didik yang bertujuan untuk melihat perkembangan peserta didik, yang meliputi: penilaian perseorangan dan kelompok sesuai dengan materi dan model pembelajaran yang akan disampaikan oleh guru pada setiap pertemuan dengan cara penilaian holistik. Dalam teknik penilaian ini yang harus dibandingkan adalah hasil karya dengan kriteria-kriteria hasil dari pencapaian materi yang merupakan kumpulan hasil kerja siswa yang menunjukkan atau memperlihatkan hasil pemikiran mereka, minat, hasil usaha, tujuan, dan cita-cita mereka dalam berbagai aspek, baik individu maupun kelompok yang sudah dibentuk. Penilaian portofolio peserta didik dilakukan dengan menggunakan rubrik pensekoran, daftar cek atau skala penilaian. Dalam rubrik pensekoran menggunakan kriteria-kriteria tertentu untuk menilai tugas portofolio siswa (Wahyuni dan Ibrahim, 20I2).

Penilaian Proyek adalah penilaian terhadap tugas yang mengandung investigasi dan harus di selesaikan dalam periode/waktu tertentu. Tugas tersebut meliputi perencanaan, pengumpulan data, pengorganisasian, pengolahan, dan penyajian data. Proyek juga akan memberikan informasi tentang pemahaman dan pengetahuan siswa dalam mengaplikasikan pengetahuan dan kemampuan siswa untuk mengkomunikasikan informasi (Kurniasih dan Sani, 20I4). Penilaian proyek sangat membantu dalam mengembangkan keterampilan berpikir tinggi (berpikir kritis, pemecahan masalah, dan berpikir kreatif) bagi para peserta didik. Penilaian Proyek dapat juga digunakan untuk mengetahui pemahaman, kemampuan mengaplikasikan, kemampuan penyelidikan, dan kemampuan menginformasikan peserta didik, pada mata pelajaran tertentu secara jelas. Selama mengerjakan sebuah proyek pembelajaran, peserta didik memperoleh kesempatan untuk mengaplikasikan sikap, keterampilan dan pengetahuannya. Karena itu, pada setiap Penilaian Proyek, setidaknya ada tiga hal yang perlu diberikan perhatian khusus oleh guru, yaitu: (I) Keterampilan peserta didik dalam memilih topik, mencari dan mengumpulkan data, mengolah dan menganalisis, memberi makna atas informasi yang diperoleh, dan menulis laporan. (2) Kesesuaian atau relevansi materi pembelajaran dengan pengembangan sikap, keterampilan, dan pengetahuan yang dibutuhkan oleh peserta didik. 
(3) Orisinalitas atau keaslian sebuah proyek pembelajaran yang dikerjakan atau dihasilkan oleh peserta didik. Pada Penilaian Proyek dapat menggunakan instrumen daftar cek, skala penilaian, atau narasi (Hosnan, 20l4). Karena dalam bentuk penilaian ini melibatkan hasil atau produk yang akan dihasilkan siswa, oleh karena itu penilaian akan dilakukan dengan menggunakan instrumen yang sesuai dengan materi yang terkait selama proses pembelajaran berlangsung. Penilaian Proyek adalah investigasi mendalam mengenai suatu topik nyata. Pelaksanaan Penilaian Proyek dapat dianalogikan dengan sebuah cerita, yaitu: memiliki fase awal, pertengahan, dan akhir proyek. Selanjutnya Penilaian Proyek dapat melibatkan siswa ke dalam masalah atau situasi yang dapat membimbing siswa memformulasikan pertanyaan atau membuat dugaan yang memerlukan investigasi lebih lanjut (Muslich, 20II). Penilaian Proyek juga memberikan kesempatan bagi siswa secara berkelompok untuk mengungkapkan ide-ide dalam mata pelajaran Bahasa Inggris dengan menggunakan materimateri yang terkait dengan penilaian proyek yang dilakukan oleh siswa secara berkelompok. Hasil dari penilaian proyek yang berupa produk dimaksud meliputi penilaian atas kemampuan peserta didik menghasilkan produk/karya sesuai standar kompetensi yang diharapkan pada setiap mata pelajaran.

Penilaian proyek berfokus pada perencanaan, pengerjaan, dan produk proyek. Dalam kaitan ini, rangkaian yang harus dilakukan oleh guru meliputi penyusunan rancangan dan instrumen penilaian pengumpulan data, analisis data, dan menyiapkan laporan. Selama mengerjakan sebuah proyek pembelajaran, peserta didik memperoleh kesempatan untuk mengaplikasikan sikap, keterampilan, dan pengetahuannya. Pelaksanaan Penilaian Proyek dapat menggunakan alat/ instrumen penilaian berupa daftar cek ataupun skala penilaian. Berikut ini format dan rubrik pensekoran umum untuk Penilaian Proyek ketika siswa secara berkelompok diberi tugas membuat sebuah proyek dalam waktu yang dibatasi (Wahyuni dan Ibrahim, 20I2).

Model Pembelajaran adalah kegiatan pembelajaran inquiry diawali dengan eksplorasi konsep, memberikan kesempatan kepada siswa untuk mengemukakan gagasan sesuai dengan pengetahuan awal yang mereka miliki. Siswa diberi kesempatan untuk mencari sendiri jawaban permasalahan yang diberikan, dan hal lainnya berkaitan dengan pengamatan dan pengalaman sendiri. Dengan demikian, Model Pembelajaran ini diduga dapat meningkatkan intelektual siswa (Hamdani, 20II). Jadi pada dasarnya siswa dituntut untuk lebih kreatif dalam memandang suatu permasalahan dan memiliki pola pikir yang baik atas solusi bagi permasalahan tersebut yang diberikan oleh guru dan berkaitan dengan materi selama proses pembelajaran berlangsung.

Menurut Smith, Collaborative Learning atau pembelajaran melalui kerja sama adalah jenis pendekatan pendidikan yang meliputi, penggabungan karya/usaha intelektual siswa, atau siswa bersama dengan guru. Biasanya, siswa bekerja dalam 2 kelompok atau lebih, saling mencari pemahaman, penyelesaian atau arti, atau membentuk suatu produk/hasil (Hosnan, 20I4:308). "Collaborative Learning is often cited as a means to a productive educational experience for students. With this in mind, designer and researchers have taken to building technologies that support various forms of collaborative activity in schools and other learning environments". Dengan pengertian di sini penekanannya adalah sebagai pengalaman pembelajaran yang produktif bagi siswa. Dengan pemikiran, seorang desain dan peneliti ingin membangun teknologi untuk mendukung berbagai macam bentuk kegiatan pembelajaran kolaboratif di sekolah dan kegiatan pembelajaran di lingkungan sekitar (Spector dkk, 20I3). Karena bentuk kolaboratif ini adalah bentuk saling kerja sama dalam pengerjaan tugas untuk saling membantu mendapatkan berbagai macam informasi sebagai kelengkapan jawaban atas tugas yang telah disampaikan oleh guru tanpa harus bergantung antar teman, karena pada saat pengumpulan tugas jawaban individu masingmasing siswa sangat diperlukan. Karena pada dasarnya dalam model pembelajaran kolaboratif ini mengutamakan kebersamaan antar teman dalam pembelajaran secara berkelompok dengan menyumbangkan ide-ide yang kreatif dan informatif selama proses kegiatan belajar mengajar di kelas. Lebih spesifik Pembelajaran Kolaboratif ini lebih menekankan pada pembangunan makna oleh siswa dari proses sosial yang bertumpu pada konteks belajar (Thobroni 
dan Mustofa, 2013). Jadi siswa diberi pengertian bahwa setiap kebersamaan dalam sebuah kelompok yang disusun untuk memecahkan permasalahan yang sesuai dengan materi harus timbul rasa kebersamaan antar anggota dan bukan pemikiran yang individu.

Student Team-Achievement Division (STAD) adalah satu model pembelajaran kolaboratif yang paling tua dan paling banyak diteliti, karena model ini telah banyak diaplikasikan mulai dari sekolah dasar sampai pendidikan atas. Student TeamAchievement Division (STAD) merupakan salah satu metode pembelajaran yang yang paling sederhana, dan merupakan model yang paling baik untuk permulaan bagi para guru yang baru menggunakan pendekatan Kolaboratif (Slavin, 2005). Dalam penjabarannya Student Team-Achievement Division (STAD) terdiri dari lima komponen utama, yaitu: Presentasi Kelas, Tim, Kuis, Skor Kemajuan Individual, dan Rekognisi Tim. Dalam model Student Team-Achievement Division (STAD) ini merupakan salah satu tipe dari model pembelajaran kolaboratif dengan menggunakan kelompok-kelompok kecil dengan jumlah anggota tiap kelompok 4-5 orang secara heterogen.

Cooperative Integrated Reading and Composition (CIRC), adalah sebuah program yang komprehensif untuk mengajarkan pelajaran, membaca, menulis, dan seni berbahasa pada kelas yang lebih tinggi (Slavin, 2005). Pengembangan Cooperative Integrated Reading and Composition (CIRC) difokuskan pada kurikulum sebagai teknik terbaru mengenai pengajaran praktis membaca dan menulis. Cooperative Integrated Reading and Composition (CIRC) membagi kelas dalam dua kelompok yang beranggotakan 8-I5 orang, satu kelompok memfokuskan pada skill-skill penyandian bunyi dan pemahaman, dan kelompok lainnya memfokuskan pada skill-skill pemahaman dan interferensi (makna). Masing-masing kelompok membaca ini dibagi lagi ke dalam kelompok membaca yang lain untuk penyelesaian tugas. Skor setiap siswa pada semua kuis, karangan dan laporan tertulis berkontribusi terhadap nilai tim dan sertifikat yang diberikan. Para siswa dinilai berdasarkan hasil kerja mereka masing-masing (Johnson, 2010). Struktur dalam Cooperative Integrated Reading and Composition (CIRC) ini menurut Casal dalam hal pengembangan pembelajaran bahasa terutama ditekankan dalam pembelajaran membaca (Warsono dan Hariyanto, 20I3). Adapun langkah-langkah penerapan Model Cooperative Integrated Reading and Composition (CIRC) menurut Slavin adalah sebagai berikut: (I) guru membagi peserta didik menjadi dua kelompok, (2) guru memberikan wacana kepada tiap kelompok untuk dibaca dan dibuat ringkasannya, (3) guru menetapkan kelompok yang berperan sebagai penyaji dan kelompok yang berperan sebagai pendengar, (4) kelompok penyaji, membacakan ringkasan. Sementara itu kelompok pendengar: menyimak/mengoreksi/ menunjukkan ide-ide pokok yang kurang lengkap, membantu mengingat/menghafal ide-ide pokok dengan menghubungkan materi sebelumnya, kelompok bertukar peran, yaitu: kelompok yang semula sebagai penyaji menjadi pendengar dan kelompok pendengar menjadi penyaji, peserta didik menyimpulkan hasil diskusi bersama-sama (Sani, 20I3).

Hasil penelitian Dewi (2014) mendapatkan sebuah penemuan bahwa kelas eksperimen diberi perlakuan strategi pembelajaran kolaboratif sedangkan kelas kontrol diberikan strategi pembelajaran korporatif. Hasil penelitian menunjukkan terdapat perbedaan antara pemberian strategi pembelajaran kolaboratif dengan pemberian strategi pembelajaran korporatif pada kelompok siswa dengan kemampuan awal tinggi.

Penelitian ini bertujuan untuk mengetahui pengaruh perbedaan dan interaksi antara model pembelajaran kolaboratif dan asesmen autentik terhadap hasil belajar Bahasa Inggris siswa SMP di kota Malang.

\section{Metode Penelitian}

Pendekatan yang digunakan dalam penelitian ini menggunakan penelitian eksperimen dengan desain faktorial $2 \times 2$. Populasi target dalam penelitian ini adalah seluruh siswa SMP Islam Maarif 02 Malang dan SMPN 19 Malang yang sama-sama memiliki akreditasi A di Kota Malang dan populasi terjangkau adalah siswa kelas VII di SMP Islam Maarif 02 Malang dan SMPN 19 di Kota Malang. Pengambilan sampel dilakukan secara multi-stage random sampling, sebanyak 96 orang siswa, dengan masing-masing sel sebanyak 24 orang. 
Tabel I. Desain Penelitian Faktorial $2 \times 2$

\begin{tabular}{ccc}
\hline $\begin{array}{c}\text { Asesmen } \\
\text { Autentik } \\
(\mathbf{B})\end{array}$ & \multicolumn{2}{c}{$\begin{array}{c}\text { Model Pembelajaran } \\
(\mathbf{A})\end{array}$} \\
\cline { 2 - 3 } & $\operatorname{STAD}\left(\mathrm{A}_{1}\right)$ & $\operatorname{CIRC}\left(\mathrm{A}_{2}\right)$ \\
\hline $\begin{array}{c}\text { Portofolio } \\
\left(\mathrm{B}_{1}\right)\end{array}$ & $\mathrm{A}_{1} \mathrm{~B}_{1}$ & $\mathrm{~A}_{2} \mathrm{~B}_{1}$ \\
\hline $\begin{array}{c}\text { Proyek } \\
\left(\mathrm{B}_{2}\right)\end{array}$ & $\mathrm{A}_{1} \mathrm{~B}_{2}$ & $\mathrm{~A}_{2} \mathrm{~B}_{2}$ \\
\hline
\end{tabular}

Keterangan :

$A_{1}=$ Model Pembelajaran Kolaboratif Student Team Achievement Division(STAD)

$A_{2}=$ Model Pembelajaran Kolaboratif Cooperative Integrated Reading and Composition (CIRC)

$B_{1}=$ Asesmen Autentik bentuk Penilaian Portofolio

$\mathrm{B}_{2}=$ Asesmen Autentik bentuk Penilaian Proyek

$A_{1} B_{1}=$ Kelompok siswa yang diberikan Model Pembelajaran Kolaboratif jenis STAD dengan menggunakan Asesmen Autentik bentuk Penilaian Portofolio

$A_{1} B_{2}=$ Kelompok siswa yang diberikan Model Pembelajaran Kolaboratif jenis STAD dengan menggunakan Asesmen autentik bentuk Penilaian Proyek

$\mathrm{A}_{2} \mathrm{~B}_{1}=$ Kelompok siswa yang diberi Model Pembelajaran Kolaboratif jenis CIRC dengan menggunakan Asesmen Autentik jenis Penilaian Portofolio

$\mathrm{A}_{2} \mathrm{~B}_{2}=$ Kelompok siswa yang diberi Model Pembelajaran Kolaboratif jenis CIRC dengan menggunakan Asesmen Autentik jenis Penilaian Proyek

Instrumen tes hasil belajar menggunakan pilihan ganda. Uji persyaratan analisis yang terdiri dari uji normalitas, uji homogenitas semua telah teruji. Analisis data untuk menguji hipotesis menggunakan Analisis Varian (ANAVA) dua jalur, dengan olah data menggunakan Microsoft Excel.

\section{Hasil Penelitian dan Pembahasan}

Untuk mengetahui deskripsi data hasil penelitian yang telah dilakukan, dapat dilihat pada Tabel 2 yang menunjukkan bahwa hasil belajar Bahasa Inggris kelompok siswa yang diberi model pembelajaran STAD lebih tinggi dari kelompok siswa yang diberi model pembelajaran CIRC.

Tabel 2. Deskripsi Keseluruhan Data

\begin{tabular}{|c|c|c|c|c|c|c|c|c|}
\hline \multirow{2}{*}{$\begin{array}{c}\text { Sebaran } \\
\text { Data }\end{array}$} & \multicolumn{8}{|c|}{ Kelompok Perlakuan } \\
\hline & $\overline{A_{1}}$ & $\overline{A_{2}}$ & $\mathbf{B}_{\mathbf{I}}$ & $\mathbf{B}_{2}$ & $\overline{A_{1} B_{1}}$ & $\mathbf{A}_{1} \mathbf{B}_{2}$ & $\overline{\mathbf{A}_{2} \mathbf{B}_{1}}$ & $\mathbf{A}_{2} \mathbf{B}_{2}$ \\
\hline Sampel (N) & 48 & 48 & 48 & 48 & 24 & 24 & 24 & 24 \\
\hline Mean & 19,37 & 16,79 & 19,12 & 17,5 & 19,25 & 17,1 & 17,6 & 15.83 \\
\hline Median & 18,96 & $|7,3|$ & 20,31 & 16,53 & 19,23 & 18.15 & 18,42 & 17,04 \\
\hline Modus & 18 & 17,1 & 22,5 & 16,74 & 19,5 & 17,49 & 17,49 & 16,65 \\
\hline StdeV & 3,92 & 4,05 & 3,84 & 4,05 & 3.85 & 3,91 & 3,98 & 4,16 \\
\hline Variansi & 15,33 & 16.41 & 14,76 & $|6,4|$ & 14,82 & 15,27 & 15,83 & 17,34 \\
\hline Maksimum & 24 & 24 & 24 & 24 & 24 & 24 & 24 & 24 \\
\hline Minimum & II & II & II & II & II & II & II & II \\
\hline Range & 13 & 13 & 13 & 13 & 13 & 13 & 13 & 13 \\
\hline
\end{tabular}

Hasil belajar Bahasa Inggris kelompok siswa yang diberi asesmen autentik portofolio lebih tinggi dari hasil belajar kelompok siswa yang diberi asesmen autentik proyek. Hasil belajar Bahasa Inggris kelompok siswa yang diberi model pembelajaran STAD dengan asesmen autentik portofolio lebih tinggi dari hasil belajar Bahasa Inggris kelompok siswa yang diberi model pembelajaran STAD dengan asesmen autentik proyek. Hasil belajar Bahasa Inggris kelompok 
siswa yang diberi model pembelajaran CIRC dengan asesmen autentik bentuk proyek lebih rendah hasilnya daripada hasil belajar Bahasa Inggris kelompok siswa yang diberi model pembelajaran CIRC dengan asesmen autentik portofolio.

Berdasarkan Tabel 3 dapat disimpulkan bahwa terdapat pengaruh hasil belajar Bahasa Inggris antara kelompok siswa yang diberi model pembelajaran STAD dan CIRC. Terdapat pengaruh hasil belajar Bahasa Inggris antara kelompok siswa yang diberi asesmen autentik portofolio dan kelompok siswa yang diberi asesmen proyek. Terdapat pengaruh interaksi antara model pembelajaran dan asesmen autentik terhadap hasil belajar Bahasa Inggris

Tabel 3. Hasil Analisis Pengujian Hipotesis

\begin{tabular}{ccccccc}
\hline $\begin{array}{c}\text { Sumber } \\
\text { varians }\end{array}$ & JK & db & \multirow{2}{*}{ RJK } & Fo & \multicolumn{2}{c}{ F Tabel } \\
\cline { 5 - 7 } & & & & & $\alpha=0,05$ & $\alpha=0,01$ \\
\hline Antar A & 46.75 & $\mathrm{I}$ & 46.75 & $6.1 I^{*}$ & 3,94 & 6.90 \\
\hline Antar B & 44 & $\mathrm{I}$ & 44 & $5.75^{*}$ & & \\
\hline Interaksi AB & 215.37 & $\mathrm{I}$ & 215.37 & $28.15^{*}$ & & \\
\hline Dalam & 704.12 & 92 & 7.65 & - & & \\
\hline Total & 1010.24 & 95 & - & - & & \\
\hline
\end{tabular}

Tabel 4. Hasil Pengujian Uji $t$

\begin{tabular}{ccc}
\hline \multirow{2}{*}{ Pengujian } & $\mathbf{t}_{\text {Hitung }}$ & $\mathbf{t}_{\text {tabel }}$ \\
\cline { 3 - 3 } & 4.60 & $\boldsymbol{\alpha}=\mathbf{0 , 0 5}$ \\
\hline $\mathrm{A}_{1} \mathrm{~B}_{1}$ dan $\mathrm{A}_{2} \mathrm{~B}_{1}$ & 0,37 & 3,90 \\
\hline $\mathrm{A}_{1} \mathrm{~B}_{2}$ dan $\mathrm{A}_{2} \mathrm{~B}_{2}$ & 4,54 & 3,90 \\
\hline $\mathrm{A}_{1} \mathrm{~B}_{1}$ dan $\mathrm{A}_{1} \mathrm{~B}_{2}$ & 0,3 & 3,90 \\
\hline $\mathrm{A}_{2} \mathrm{~B}_{1}$ dan $\mathrm{A}_{2} \mathrm{~B}_{2}$ & 3,90 \\
\hline
\end{tabular}

Berdasarkan Tabel 4 diperoleh bahwa hasil belajar siswa yang diajar dengan model pembelajaran kolaboratif STAD lebih tinggi dari model CIRC dengan menggunakan asesmen autentik portofolio. Hasil belajar siswa yang diajar dengan model pembelajaran kolaboratif STAD lebih rendah dari model CIRC dengan menggunakan asesmen autentik proyek. Hasil belajar siswa yang belajar dengan menggunakan asesmen autentik portofolio lebih tinggi dari proyek pada model pembelajaran kolaboratif STAD. Untuk yang tidak teruji berarti tidak dapat pengaruh hasil belajar Bahasa Inggris pada kelompok siswa yang diberi asesmen autentik proyek.

Hasil penelitian menunjukkan terdapat perbedaan hasil belajar kelompok siswa menggunakan model pembelajaran kolaboratif STAD lebih tinggi dibandingkan dengan CIRC. Model pembelajaran STAD dirasa siswa sangat menyenangkan dan tidak membosankan, karena dalam pembentukan kelompok pada model STAD dirasa sangat efektif karena dalam satu kelompok hanya terdiri dari 4-5 siswa. Dan pada saat diskusi pun akan terasa lebih aktif dengan adanya jumlah kelompok kecil yang mana mereka akan bekerja bersama-sama tanpa saling bergantung satu sama lain. Model seperti ini sangat cocok diterapkan dalam pelajaran Bahasa Inggris di mana dalam pelajaran ini sangat membutuhkan keaktifan siswa.

Hasil penelitian selanjutnya menunjukkan bahwa terdapat perbedaan hasil belajar Bahasa Inggris antara kelompok siswa yang diberi asesmen autentik portofolio dengan kelompok siswa yang diberi asesmen autentik proyek, setelah melihat tes hasil belajar akhir yang diberikan pada siswa. Hasil ini menunjukkan bahwa asesmen autentik yang diberikan pada siswa berpengaruh terhadap pencapaian hasil belajar Bahasa Inggris. Karakteristik asesmen autentik bentuk proyek yang cenderung selalu dan harus menghasilkan suatu karya yang orisinal 
pada mata pelajaran Bahasa Inggris akan sangat dirasa kesulitan oleh kelompok siswa. Pada asesmen proyek ini mungkin akan dirasa terlalu membebani siswa karena materi yang harus dikeluarkan untuk menghasilkan sebuah produk dengan waktu yang terbatas. Bagi siswa yang cenderung menyukai pada saat guru memberikan asesmen portofolio yang mungkin sesuai dengan karakteristik Bahasa Inggris, siswa akan merasa lebih tidak bosan bahkan lebih termotivasi.

Terdapat pengaruh interaksi antara model pembelajaran kolaboratif dan asesmen autentik terhadap hasil belajar Bahasa Inggris setelah melihat tes hasil belajar. Pada interaksi antara model pembelajaran kolaboratif dan asesmen autentik terhadap hasil belajar Bahasa Inggris setelah melihat tes hasil belajar. hal ini menunjukkan bahwa pengaruh model pembelajaran terhadap hasil belajar Bahasa Inggris bergantung pada asesmen autentik yang diberikan setelah melihat tes akhir.

Hasil penelitian menunjukkan bahwa terdapat perbedaan hasil belajar Bahasa Inggris antara kelompok siswa yang menggunakan model pembelajaran kolaboratif STAD dan model pembelajaran CIRC serta memiliki kecenderungan yang diberi asesmen autentik portofolio, setelah melihat tes hasil belajar. Secara teoretik karakteristik siswa yang diberi asesmen autentik portofolio memang sangat sesuai dengan karakteristik model pembelajaran kolaboratif STAD. Model pembelajaran kolaboratif jenis STAD lebih memberikan kebebasan pada siswa agar lebih aktif dan kreatif serta memberikan kebebasan dalam berkreasi dalam pengumpulan tugas sehari-hari terkait dengan materi pelajaran Bahasa Inggris dan tidak terlalu membebankan pada siswa.

Hasil penelitian menunjukkan bahwa hasil belajar Bahasa Inggris antara kelompok siswa yang diberikan model STAD lebih rendah daripada model CIRC dengan pemberian asesmen autentik proyek, setelah melihat tes hasil belajar Bahasa Inggris siswa. Siswa yang diberi asesmen autentik bentuk proyek tidak relevan dengan karakteristik materi pelajaran Bahasa Inggris yang cocok dengan model pembelajaran STAD dan asesmen autentik portofolio. Kecenderungan asesmen autentik proyek yang selalu harus menghasilkan sebuah produk yang orisinal yang dirasa sangat membosankan dan juga memberatkan siswa dirasa kurang cocok dengan karakteristik pelajaran Bahasa Inggris. Karena itu bagi siswa yang memiliki kecenderungan pada asesmen autentik proyek kurang memberikan pengaruh terhadap hasil belajar Bahasa Inggris meskipun diberikan model pembelajaran STAD maupun CIRC.

Hasil penelitian selanjutnya menunjukkan bahwa kelompok siswa yang diberi asesmen autentik portofolio lebih tinggi dari pada kelompok siswa yang diberi asesmen proyek menggunakan model pembelajaran STAD, setelah melihat tes hasil belajar Bahasa Inggris. Asesmen autentik portofolio adalah semacam penilaian yang mengukur tingkat kreativitas siswa dalam pengerjaan tugas sehari-hari sesuai dengan materi yang disampaikan dengan cara yang menyenangkan. Karena itu tidaklah terlalu mengherankan apabila hasil belajar Bahasa Inggris bagi siswa yang diberi asesmen autentik portofolio dengan menggunakan model pembelajaran STAD, lebih tinggi daripada hasil belajar yang diberikan asesmen bentuk proyek setelah melihat tes hasil belajarnya.

Apalagi yang cenderung diberi asesmen autentik proyek yang selalu harus menghasilkan produk yang orisinal. Siswa akan merasa bahwa penilaian tersebut sangat membosankan dan memberatkan. Terkadang juga penilaian tersebut membuat kelompok siswa akan saling menggantungkan tugasnya pada rekan satu kelompok yang mungkin memiliki kecenderungan siswa yang suka diberi asesmen autentik proyek dalam setiap penugasan.

Karena itu karakteristik model pembelajaran STAD serta karakteristik materi pelajaran Bahasa Inggris sangat cocok dengan karakteristik siswa yang memiliki kecenderungan diberi asesmen autentik bentuk portofolio dibanding siswa yang cenderung diberi asesmen autentik bentuk proyek.

\section{Kesimpulan}

Hasil penelitian menyimpulkan sebagai berikut: hasil belajar Bahasa Inggris kelompok siswa menggunakan model pembelajaran kolaboratif STAD lebih tinggi dibandingkan dengan CIRC. Terdapat perbedaan hasil belajar Bahasa Inggris 
antara kelompok siswa yang diberi asesmen autentik portofolio dengan kelompok siswa yang diberi asesmen autentik proyek, setelah melihat tes hasil belajar akhir yang diberikan pada siswa. Terdapat pengaruh interaksi antara model pembelajaran kolaboratif dan asesmen autentik terhadap hasil belajar Bahasa Inggris. Terdapat perbedaan hasil belajar Bahasa Inggris antara kelompok siswa yang menggunakan model pembelajaran kolaboratif STAD dan CIRC serta memiliki kecenderungan yang diberi asesmen autentik portofolio. Hasil belajar Bahasa Inggris antara kelompok siswa yang diberikan model STAD lebih rendah daripada model CIRC dengan pemberian asesmen autentik proyek. Terdapat kelompok siswa yang diberi asesmen autentik portofolio lebih tinggi dari pada yang diberi asesmen proyek menggunakan model pembelajaran STAD. Selanjutnya untuk guru yang mengajarkan pelajaran Bahasa Inggris diharapkan memperhatikan model pembelajaran yang cocok bagi siswa.

\section{Daftar Pustaka}

Darminah, dkk. (20ll). Buku Materi Pokok Pengembangan Kurikulum dan Pembelajaran Bahasa Inggris. Jakarta: Universitas Terbuka.

Dewi, Sofia. (20/4). "Pengaruh Strategi Pembelajaran Kolaboratif dengan Strategi Pembelajaran Kompetitif'. Tesis, Universitas Negeri Jakarta.

Djaali dan Pudji Muljono. (2008). Pengukuran dalam Bidang Pendidikan. Jakarta: Grasindo.

Hamdani. (20II). Strategi Belajar Mengajar. Bandung: Pustaka Setia.

Hosnan, M. (20|4). Pendekatan Saintifik dan Kontekstual dalam Pembelajaran Abad 2I. Bogor: Ghalia Indonesia.

Imas, Kurniasih dan Berlin Sani. (20/4). Implementasi Kurikulum 2013 Konsep dan Penerapan. Surabaya: Kata Pena.

Jihad, Asep dan Abdul Haris. (20I2). Evaluasi Pembelajaran. Yogyakarta: Multi Presindo.
Johnson, David W., Roger T. Johnson, dan Edythe Johnson Holubec. (2010). Collaborative Learning: Strategi Pembelajaran untuk Sukses Bersama, terjemahan Narulita Yusron. Bandung: Nusamedia.

Kunandar. (20/4). Penilaian Autentik. Jakarta: PT. Raja Grafindo Persada.

Muslich, Masnur. (20II). Authenthic Assessment: Penilaian Berbasis Kelas dan Kompetensi Bandung: Refika Aditama.

Rasyid, Harun dan Mansur. (2009). Penilaian Hasil Belajar. Bandung: CV. Wacana Prima.

Sani, Ridwan Abdullah. (20/3). Inovasi Pembelajaran. Jakarta: PT. Bumi Aksara.

Slavin, Robert. E. (20I4). Cooperative Learning, terjemahan Narulita Yusron. Bandung: Nusa Media.

Spector, J. Michael., M. David Merrill, Jeroen Van Merrienboer, dan Marcy P. Driscoll. (20II). Handbook of Research On Educational Communications and Technology. New York: Lawrence Erlbaum Associates.

Thobroni, Muhammad dan Arif Mustofa. (20I3). Belajar dan Pembelajaran Pengembangan Wacana dan Praktik Pembelajaran dalam Pembangunan Nasional. Yogyakarta: ARRuzz Media.

Wahyuni, Sri dan Abdul Syukur Ibrahim. (20I2). Asesmen Pembelajaran Bahasa. Bandung: Refika Aditama.

Warsono dan Hariyanto. (2013). Pembelajaran Aktif Teori dan Asesmen. Bandung: PT. Remaja Rosdakarya.

Wiyani, Novan Ardy. (20I3). Desain Pembelajaran Pendidikan. Yogyakarta: AR-RUZZ Media. 